\title{
Football and family violence: Learning from the experience of Great Britain
}

\author{
K. Zalcmane \\ Rīga Stradinsš University, Riga, Latvia
}

\begin{abstract}
The aim of the article is to analyse the methodological issues of the study of criminologist Dr. Stuart Kirby (Lancaster University) on the link between the football game and domestic violence committed by football fans. The mentioned above study at the moment is one of a kind in Europe. The author assumes, the similar research should be held in Latvia and any other European country as well, as understanding the primary reason of a crime can lead to the most appropriate intervention to reduce or remove it. For that reason, the analysis of the prospective advantages and disadvantages of the Dr. Kirby research are presented in this article.
\end{abstract}

Violence appears in sports quite often. Many sports are just a bit violent by its nature and are not a major concern in today's society. Unfortunately, cases of domestic violence committed by sportsmen or/and fans have become part of the world of sports as well. Cases of domestic violence committed by sportsmen are widely discussed by academics, society and law enforcement agencies. However, almost nothing is said about those family members who are scared to death, when they find out the favourite team of their relatives lost the game.

Nevertheless, there is one research project in Europe that empirically proved the link between watching football and domestic violence. The criminologist Dr. Stuart Kirby (a former police officer) and Professor Brian Francis of Lancaster University with Rosalie O'Flaherty analysed figures from Lancashire Constabulary across three tournaments (World Cups) in 2002, 2006, and 2010. In year 2013, the mentioned above group of the researchers concluded that incidents of domestic abuse rose by 38 per cent in Lancashire when the England team played and lost, and increased by 26 per cent when the England national team played and won or drew compared with days when there was no England match [1]. There was also a carry-over effect, with incidents of domestic abuse, $11 \%$ higher the day after an England match [1].

As was mentioned before, the research of Dr. Kirby and his colleagues is one of a kind in Europe at the moment. The author assumes, the similar research should be held in Latvia and any other European country as well, as understanding the primary reason of a crime can lead to the most appropriate intervention to reduce or remove it. For that reason, methodological issues of the research on a link between watching a football game and domestic violence will be discussed and analysed in this article.

In order to start the discussion of the prospective advantages and disadvantages of the research methodology, it is important to point out main advantages of the mentioned above study itself. First of all, the research project proved empirically that the football tournaments that have been watched in Great Britain can be associated with a rise in reported domestic abuse incidents. Secondly, football continues to develop as a global business. The English Premier League, for example, involves 337 foreign players from 66 countries with games being televised to over 200 countries. Other European leagues, such as La Liga (Spain), Serie 
A (Italy) and Bundesliga (Germany) are also televised internationally with the European Champions League final watched by 109 million people across the world [1]. That means, hundreds of millions people may react inappropriately, in case of the disappointment of an unexpected loss and alcohol use. There is a plenty empirical research projects which proved the link between the viewing of football and increased reports of assault, vandalism and arrests for disorderly conduct and alcohol related offences on a day of the game. However, none of them, apart from the mentioned above research project, discuss the problem of physical or moral abuse in the family of aggressive fan. Hence, study of Dr. Kirby \& Co proved the domestic violence in a football fans family is not a social myth.

Dr. Kirby and his colleagues pointed out numerous methodological issues of the study themselves, the most obvious being the identification of what is a family violence. The term family violence is a synonym of "domestic abuse" and "domestic violence" and those two terms are often interchanged [1].

The British government do not divide those two terms and define them as "any incident or pattern of incidents of controlling, coercive, threatening behaviour, violence or abuse between those aged 16 or over who are, or have been, intimate partners or family members regardless of gender or sexuality. The abuse can encompass, but is not limited to psychological, physical, sexual, financial, and emotional" [2]. However, Dr. Kirby concluded that there is a difference between those two terms. In his opinion, domestic violence more often describes just physical assault, whereas domestic abuse should be defined more widely and can include physical, psychological, sexual or financial violence.

In case similar research will be held in Latvia, the local researchers should take into account that regulating acts in Latvia do not provide a definition of terms "Family violence", "domestic abuse" and/or "domestic violence" [3]. For that reason, it is not possible, at the moment, to identify, whether there is difference between those terms, what they mean and how exactly they differ from other offences in Latvia. The other problem that could be faced by Latvian, and not only, researchers is that there is no commonly accepted definition for the term "domestic". In the case of domestic abuse or violence, it could include violence or abuse between spouses or between parents and children, between non-married partners, siblings, or between those in other familial relationships. This diversity conjures up significant difficulty when trying to measure the extent of the problem [1].

When the scope of the definition is determined, a new difficulty arises - obtaining accurate data. In accordance to Dr. Kirby study, the most reliable data could be obtained from the police data [1]. However, it is worldwide-proved fact, that only third part of all domestic violence is usually reported. For that reason, family violence is considered as the "hidden violence" [4]. However, one of the benefits of UK police data is that domestic abuse incidents are monitored separately from other violent crime [1]. Latvia has no statistics that would disclose the prevalence of domestic violence and problems associated to it [5]. The only reliable data could be obtained from Women's resource centre Marta (hereinafter MARTA) and/or from Ministry of Welfare of the Republic of Latvia, as those are the only ones that conduct surveys on the violence, where the victims are either women or children. Nevertheless, only MARTA separates family violence from all other types of violence, while analysing data from the surveys.

The other problem after having established that police data or data from any other reliable organisation could be used as the source of analysis - is to identify the tournament or a team in general which could be considered as most watched on the territory of the country or highly supported by the residents of this country. For the UK researchers it was not a problem, as in Britain football is considered as the national sport. For example, the average match attendances of the FC Manchester United in domestic league matches was 75205 people 
during the season 2013/14 [6], which is the second place in the Top 100 European Football Clubs Ranked by Average Attendance 2014.

In case of Latvia, it is highly important to identify, whether the aim of the research project is to highlight the link between watching national football games and family violence or watching football in general and family violence. According to statistics of the SMScredit.lv Latvian Higher League season 2013/2014, the game of FC "Liepaja" and FC "Daugava" (Riga) was the most viewed (one thousand and nine hundred people inside the stadium) in Latvia [7]. Nevertheless, the author of this article suggests to organise firstly a separate survey on the most watched football tournament in Latvia and afterwards to start a research on the link between watching the football game and family violence. As was concluded by Dr. Kirby, even though the tournament is staged thousands of miles away the live imagery and media commentary is transmitted into homes and social areas, replicating many of the emotions associated with viewing the game in a live environment [1]. These emotional stressors are combined with other situational factors, as the tournament is held in the summer and is associated with warmer temperatures, increased alcohol consumption and brings individuals in closer proximity to others [1].

After the main possible difficulties of the research have been discussed, it is highly important to point out potential prevention measures for this kind of crime. Dr. Kirby assumes that the best approach to combat this kind of crime could be the situational crime prevention.

According to Dr. Ronald V. Clarke's theory, the situational crime prevention is focused on the settings of crime rather than on detection and sanction of offenders; it seeks not to eliminate criminal or delinquent tendencies through improvement of society or its institutions, but merely to make criminal action less attractive to offenders [8].

For example, the social calendar 2012 of Ukrainian football team "Karpaty" (Lviv) is a good illustration of situational crime prevention. The calendar was created in cooperation with the project management of EU "The rights of children and women in Ukraine". In this calendar, the football players call all fans with the personal quotes like: "I use my power only in order to win in a fair game, but not in relation to the loved ones". In this case, the preventive measure is a publication of the contempt of domestic violence by professional players involved in the tournament, thereby distancing the aggression on the pitch from the domestic environment [1]. Moreover, not only players could be involved in the prevention, the club with its authorities should be a part of it as well. A Women's Aid spokeswoman told to one of the British newspaper correspondents that one of the ways through which clubs could send a clear message that violence against women is totally unacceptable would be by "discouraging sexist football chants" by fans [9].

The other positive preventive measure could be a warning to a potential offender. For example, in Essex (County of England) 117 fans, seven of them women, were reportedly handed warnings after officers analysed their history of domestic and football crime [10].

However, unfortunately, the football community is not taking as much action as it could. The Football Association (governing body of football in England), for example, before the World Cup 2014, used to say it could not comment on what was not a football matter, while the Football Supporters' Federation said domestic abuse was not one of its policy areas and it had to represent the views of its members [11]. The only possible explanation of it could be that there is not much empirical evidence and public pressure on the football authorities in Europe. For example, the Refuge chief executive Sandra Horley said: "It's important to be clear - football does not cause domestic violence. Many men who abuse women have no interest in sport whatsoever, and many men who are avid football fans never lay a finger on their partners. [...] Domestic violence happens all year round - whether the England football team is playing or not. [...] The police should encourage women to reach out for support every 
day of the year, not just during the World Cup [... ]" [12]. Consequently, it is quite important to prove empirically whether there is a link between watching football and a family violence in the whole Europe.

\section{References}

[1] S. Kirby, B. Francis \& R. O'Flaherty, Can the FIFA World Cup Football (Soccer) Tournament Be Associated with an Increase in Domestic Abuse? J. of Res. in Cr. and Delin. 51 (3) 259-276 (2014).

[2] Home office, Domestic violence and abuse (Last updated 2015, March 27) Access from https://www.gov.uk/domestic-violence-and-abuse\#domestic-violenceand-abuse-new-definition (2015, May 26).

[3] European Institute of Gender Equality, Legal definition on Gender-based violence Access from http://eige.europa.eu/gender-based-violence/legaldefinitions?page $=1 \& v t[0]=950$ (2015, May 26).

[4] J. Richardson, G. Feder, Domestic violence: a hidden problem for general practice. $\mathrm{Br}$ J Gen Pract. 46 (405) 239-242 (1996).

[5] MARTA, Domestic violence Access from http://marta.lv/marta-in-action/ domestic-violence (2015, May 27).

[6] Top 100 European Football Clubs Ranked by Average Attendance 2014 (2014, July 12) Access from http://www.footballeconomy.com/content/top-100european-football-clubs-ranked-average-attendance-2014 (2015, May 27).

[7] A. Suveizda, Virslīgas apmeklējums ievērojami krities, visvairāk skatītāju Liepājā (2014, August 25) Access from http://sportacentrs.com/futbols/ virsliga/25082014-virsligas_apmeklejums_ieverojami_krities_?is_ mobile= 1 (2015, May 27).

[8] RV. Clarke, Situational crime prevention: successful case studies 2 ed. Harrow and Heston: New York (1997).

[9] Theresa May backs World Cup domestic violence clampdown campaign (last updated 2014, June 10) Access from http://www.telegraph.co.uk/women/womenslife/10887223/World-Cup-domestic-violence-clampdown-Theresa-Maylends-support-to-football-campaign.html?mobile= basic (2014, November 25).

[10] Mail online, Domestic abusers issued with warnings by police ahead of England's first World Cup game after evidence reveals incidents spike after a match - even if the team wins (2014, June 9) Access from http://www.dailymail.co.uk/news/ article-2652697/Domestic-abusers-issued-warnings-police-aheadEnglands-World-Cup-match-evidence-reveals-incidents-spike-matchteam-wins.html (2014, November 25).

[11] R. Cafe Euro 2012: Tournament football and domestic violence (2012, June 11) Access from http: //www . bbc . com/news/uk-england-18379093 (2014, November 25).

[12] Refuge statement on football and domestic violence Access from http://www.refuge.org.uk/2014/06/11/refuge-statement-on-footballand-domestic-violence/ (2015, May 27). 